\title{
Multi-criteria blocking flow shop scheduling problems: Formulation and performance analysis
}

\author{
Lebbar, G. ${ }^{\text {a, }}{ }^{*}$, El Abbassi, I. ${ }^{\text {, }}$, Jabri, A. ${ }^{c}$, El Barkany, A. ${ }^{d}$, Darcherif, M. ${ }^{e}$ \\ ${ }^{a, c, d}$ Mechanical Engineering Laboratory, Faculty of Sciences and Techniques, Fez, Morocco \\ a,b,e ECAM-EPMI, Research Laboratory in Industrial Eco-innovation and Energetics Quartz-Lab, Cergy-Pontoise, France
}

\begin{abstract}
A B S T R A C T
Most of the prior investigations related to production scheduling problems have solely focused on the optimization of an individual criterion under a single constraint; nevertheless, this is most of the time out of true in a real situation. This paper deals with multi machines permutation flow shop scheduling with limited buffers capacity and different release dates of jobs, where the performance is measured by the minimization of the weighted sum of maximum tardiness and makespan. To tackle this NP-hard problem, we present a mixed-integer linear programming model (MILP). Thereafter, using CPLEX software, we generate a set of tests in an endeavor to examine formulation for dissimilar size problems in terms of optimality solution and computational CPU time complexity. Experiment results show that overall the proposed model is computationally avaricious to solve the considering problem.

(C) 2018 PEI, University of Maribor. All rights reserved.
\end{abstract}

\begin{tabular}{l} 
A R T I C L E I N F O \\
\hline Keywords: \\
Permutation flow shop scheduling; \\
Tardiness; \\
Makespan; \\
Limited buffer; \\
Release date; \\
Mixed-integer linear programming \\
model (MILP); \\
CPLEX software \\
*Corresponding author: \\
ghitalebbar.gl@gmail.com \\
(Lebbar, G.) \\
Article history: \\
Received 8 July 2017 \\
Revised 6 April 2018 \\
Accepted 9 May 2018
\end{tabular}

\section{References}

[1] Graham, R.L., Lawler, E.L., Lenstra, J.K., Rinnooy Kan, A.H.G. (1979). Optimization and approximation in deterministic sequencing and scheduling: A survey, Annals of Discrete Mathematics, Vol. 5, 287-326, doi: 10.1016/ S0167-5060(08)70356-X.

[2] Chu, C. (1992). A branch-and-bound algorithm to minimize total tardiness with different release dates, Naval Research Logistics (NRL), Vol. 39, No. 2, 265-283, doi: 10.1002/1520-6750(199203)39:2<265::AID-NAV322039 0209>3.0.CO;2-L.

[3] Lebbar, G., El Barkany, A., Jabri, A. (2016). Scheduling problems of flexible manufacturing systems: Review, classification and opportunities, International Journal of Engineering Research in Africa, Vol. 26, 142-160, doi: 10.4028/www.scientific.net/IERA.26.142.

[4] Trabelsi, W. (2012). Ordonnancement des systèmes de production flexibles soumis à différents types de contraintes de blocage, Recherche opérationnelle [cs.RO], Universite de Lorraine, France.

[5] Wang, L., Zhang, L., Zheng, D.-Z., (2006). An effective hybrid genetic algorithm for flow shop scheduling with limited buffers, Computers \& Operations Research, Vol. 33, No. 10, 2960-2971, doi: 10.1016/j.cor.2005.02.028.

[6] Tasgetiren, M.F., Kizilay, D., Pan, Q.-K., Suganthan, P.N. (2017). Iterated greedy algorithms for the blocking flow shop scheduling problem with makespan criterion, Computers \& Operations Research, Vol. 77, 111-126, doi: 10.1016/j.cor.2016.07.002.

[7] Sadaqa, M., Moraga, R.J. (2015). Scheduling blocking flow shops using Meta-RaPS, Procedia Computer Science, Vol. 61, 533-538, doi: 10.1016/i.procs.2015.09.211. 
[8] Moslehi, G., Khorasanian, D. (2013). Optimizing blocking flow shop scheduling problem with total completion time criterion, Computers \& Operations Research, Vol. 40, No. 7, 1874-1883, doi: 10.1016/i.cor.2013.02.003.

[9] Eddaly, M., Jarboui, B., Siarry, P. (2016). Combinatorial particle swarm optimization for solving blocking flow shop scheduling problem, Journal of Computational Design and Engineering, Vol. 3, No. 4, 295-311, doi: $10.1016 /$ j.jcde.2016.05.001.

[10] Abouei Ardakan, M., Hakimian, A., Rezvan, M.T. (2014). A branch-and-bound algorithm for minimizing the number of tardy jobs in a two-machine flow-shop problem with release dates, International Journal of Computer Integrated Manufacturing, Vol. 27, No. 6, 519-528, doi: 10.1080/0951192X.2013.820349.

[11] Kalczynski, P.J., Kamburowski, J. (2012). An empirical analysis of heuristics for solving the two-machine flow shop problem with job release times, Computers \& Operations Research, Vol. 39, No. 11, 2659-2665, doi: 10.1016 Lj.cor.2012.01.011.

[12] Huang, X.W., Zhao, X.Y., Ma, X.L. (2014). An improved genetic algorithm for job-shop scheduling problem with process sequence flexibility, International Journal of Simulation Modelling, Vol. 13, No. 4, 510-522, doi: 10.2507/ IJSIMM13(4)CO20.

[13] Xu, H., Bao, Z.R., Zhang, T. (2017). Solving dual flexible job-shop scheduling problem using a Bat Algorithm, Advances in Production Engineering \& Management, Vol. 12, No. 1, 5-16, doi: 10.14743/apem2017.1.235.

[14] Yeh, W.-C. (1999). A new branch-and-bound approach for the $n / 2 /$ flow shop $/ \alpha F+\beta C_{\max }$ flow shop scheduling problem, Computers \& Operations Research, Vol. 26, No. 13, 1293-1310, doi: 10.1016/S0305-0548(98)00106-3.

[15] Yandra, Tamura, H. (2007). A new multiobjective genetic algorithm with heterogeneous population for solving flow shop scheduling problems, International Journal of Computer Integrated Manufacturing, Vol. 20, No. 5, 465477, doi: 10.1080/09511920601160288.

[16] Sayin, S., Karabati, S. (1999). Theory and methodology a bicriteria approach to the two-machine flow shop scheduling problem, European Journal of Operational Research, Vol. 113, No. 2, doi: 10.1016/S0377-2217(98) 00009-5.

[17] Daniels, R.L., Chambers, R.J. (1990). Multiobjective flow-shop scheduling, Naval Research Logistics (NRL), Vol. 37, No. 6, 981-995, doi: 10.1002/1520-6750(199012)37:6<981::AID-NAV3220370617>3.0.CO;2-H.

[18] Chakravarthy, K., Rajendran, C. (1999). A heuristic for scheduling in a flow shop with the bicriteria of makespan and maximum tardiness minimization, Production Planning \& Control, Vol. 10, No. 7, 707-714, doi: 10.1080/ 095372899232777.

[19] Allahverdi, A. (2004). A new heuristic for $m$-machine flow shop scheduling problem with bicriteria of makespan and maximum tardiness, Computers \& Operations Research, Vol. 31, No. 2, 157-180, doi: 10.1016/S03050548(02)00143-0.

[20] Fernandez-Viagas, V., Framinan, J.M. (2015). Efficient non-population-based algorithms for the permutation flow shop scheduling problem with makespan minimization subject to a maximum tardiness, Computers \& Operations Research, Vol. 64, 86-96, doi: 10.1016/i.cor.2015.05.006.

[21] Stafford Jr, E.F., Tseng, F.T., Gupta, J.N.D. (2005). Comparative evaluation of MILP flow shop models, Journal of the Operational Research Society, Vol. 56, No. 1, 88-101, doi: 10.1057/palgrave.jors.2601805.

[22] Ronconi, D.P., Birgin, E.G. (2012). Mixed-integer programming models for flowshop scheduling problems minimizing the total earliness and tardiness, In: Ríos-Mercado, R., Ríos-Solís, Y. (eds.), Just-in-Time Systems, Springer Optimization and Its Applications, Vol. 60, Springer, New York, 91-105, doi: 10.1007/978-1-4614-1123-9 5.

[23] Trabelsi, W., Sauvey, C., Sauer, N. (2012). Heuristics and metaheuristics for mixed blocking constraints flow shop scheduling problems, Computers \& Operations Research, Vol. 39, No. 11, 2520-2527, doi: 10.1016/j.cor.2011. $\underline{12.022 .}$.

[24] Clausen, J. (1999). Branch and bound algorithms - Principles and examples, Department of Computer Science, University of Copenhagen, 1-30.

[25] Baker, K.R., Keller, B. (2010). Solving the single-machine sequencing problem using integer programming, Computers \& Industrial Engineering, Vol. 59, No. 4, 730-735, doi: 10.1016/i.cie.2010.07.028.

[26] Emmons, H. (1969). One-machine sequencing to minimize certain functions of job tardiness, Operations Research, Vol. 17, No. 4, 701-715, doi: 10.1287/opre.17.4.701.

[27] Potts, C.N., Van Wassenhove, L.N. (1982). A decomposition algorithm for the single machine total tardiness problem, Operations Research Letters, Vol. 1, No. 5, 177-181, doi: 10.1016/0167-6377(82)90035-9.

[28] Parsamanesh, A.H., Sahraeian, R. (2015). Solving single machine sequencing to minimize maximum lateness problem using mixed integer programming, Journal of Quality Engineering and Production Optimization, Vol. 1, No. 1, 33-42, doi: $10.22070 /$ JQEP0.2015.187. 